\title{
Islamic Law and Sustainable Development Goals
}

\author{
Sohaib Mukhtar ${ }^{1}$, Zinatul Ashiqin Zainol2 ${ }^{2}$ and Sufian Jusoh ${ }^{3}$
}

\begin{abstract}
This study aims to analyze Sustainable Development Goals (SDGs) prescribed by United Nations Development Program (UNDP) under Islamic Law. This paper is qualitative method of research analyzing SDGs under verses of Holy Qur'an and traditions of Prophet Muhammad. This study found that what SDGs ask member states to do has been prescribed in Holy Qur'an and Sunnah of Prophet Muhammad way back 1400 years ago and demanded by Almighty Allah and the last Prophet Muhammad for eradication of poverty, hunger, malnutrition etc. Islamic law prohibits usury, gambling, uncertainty and other illegal activities to protect poor people of the society against rich landlords. Therefore, member states are required to follow SDGs to achieve peace, harmony and economic growth for betterment of humanity which is also a duty under verses of Holy Qur'an and traditions of Prophet Muhammad 㘕 to achieve success in this world and in the hereafter.
\end{abstract}

Keywords: Islamic law, Sustainable Development Goals, Millennium Development Goals

Abstrak. Kajian ini bertujuan untuk menganalisis Tujuan Pebangunan Berkelanjutan (SDGs) yang ditetapkan oleh Program Pembangunan PBB (UNDP) di bawah UndangUndang Islam. Penelitian ini adalah penelitian kualitatif yang menganalisis SDGs di bawah ayat-ayat Al-Qur'an dan tradisi Nabi Muhammad Penelitian ini menunjukkan bahwa apa yang SDGs tanyakan pada negara-negara anggota telah ditetapkan dalam Al-Qur'an dan Sunnah Nabi Muhammad kembali 1400 tahun yang lalu dan dituntut oleh Allah SWT dan Nabi terakhir Muhammad untuk membasmi kemiskinan, kelaparan, kekurangan zat makanan dll. Hukum Islam melarang riba, perjudian, ketidakpastian dan kegiatan haram lain untuk melindungi masyarakat miskin terhadap tuan-tuan tanah yang kaya. Negara anggota dikehendaki mengikuti SDGs untuk mencapai keamanan, keharmonian dan pertumbuhan ekonomi untuk memperbaiki kemanusiaan yang juga diatur di bawah ayat-ayat Al-Qur'an dan tradisi Nabi Muhammad untuk mencapai keselamatan di dunia dan di akhirat.

Kata kunci: Undang-undang Islam, Tujuan Pembangunan Berkelanjutan, Tujuan Pembangunan Milenium

\footnotetext{
${ }^{1}$ Faculty of Law, National University of Malaysia | sohaibmukhtar@gmail.com

${ }^{2}$ Faculty of Law, National University of Malaysia | shiqin@ukm.edu.my

3 Institute of Malaysian and International Studies, National University of Malaysia I sufian@gmail.com
} 


\section{Introduction}

This research is an analysis of Sustainable Development Goals (SDGs) under Islamic law. The study on (SDGs) under the light of Qur'anic verses and traditions of Prophet Muhammad has importance as SDGs recently adopted by United Nations Development Program (UNDP) and the same has been prescribed way back 1400 years ago in Holy Qur'an and Sunnah of Prophet Muhammad law to encourage Islamic countries of the world to follow SDGs and to please Almighty Allah in our benefit in this world and in the hereafter. Islam is the religion provide complete code of life comprehensively guides human beings in all aspects of life as Almighty Allah says, "O you who believe! Enter Islam perfectively (by obeying all rules and regulations of Islam) and do not follow footsteps of devil. Verily! He is your clear enemy" (Al-Baqarah [2]: 208).

Almighty Allah is the lawgiver complete in all good attributes and pure from all defects sent Prophet Muhammad to spread message of peace throughout the world. Almighty Allah states, "And We have sent you (O Muhammad 距) not but as a mercy for mankind/all that exists" (Al-Anbiya [21]: 107) Almighty Allah also says, "Muhammad 淽 is not father of any man among you but he is the Messenger of Allah and the last/end of the Prophets. And Allah is ever all aware of everything" (Al-Ahzab [33]: 40).

\section{Literature Review}

Holy Qur'an and Sunnah of Prophet Muhammad are two main basic sources of Islamic law hence all rules are derived from them and anything contrary to verses of Holy Qur'an and Sunnah of Prophet Muhammad is null and void. Almighty Allah says,

"O you who believe! Obey Allah and obey the Messenger (Muhammad and those of you (moslems) who are in authority. If you differ in anything amongst yourselves, refer it to Allah and His 
Messenger 政紫 if you believe in Allah and in the Last Day, that is better and more suitable for final determination" (Ali Imran [3]: 59).

"But no, by your Lord, they can have no faith until they make you (O Muhammad judge in all disputes between them and find in themselves no resistance against your decisions and accept (them) with full submission" (Ali Imran [3]: 65).

"It is not for believer, man or woman, when Allah and His Messenger have decreed a matter that they should have any option in their decision. And whoever disobeys Allah and His Messenger he has indeed strayed into plain error" (Al-Ahzab [33]: 36).

Islam is an Arabic word rooted from salama literally means peace. Moslems are required to praise each other with 'May peace and blessings be upon you'. Almighty Allah says,

"When you are greeted with greeting, greet in return with what is better than it or (at least) return it equally. Certainly, Allah is ever careful account taker of all things" (An-Nisa [4]: 86).

Prophet Muhammad said,

"By the one in whose hand is my soul! You will not enter Paradise until you believe, and you will not believe until you love one another. Shall I inform you a matter which if you do it will love one another? Spread salam among each other" (Jami At-Tirmidhi 2904).

United Nations Development Program (UNDP) established in 1965 for economic growth and sustainable development in the world under the umbrella of United Nations (UN). UNDP is an Executive Board under General Assembly of UN. UNDP publishes global, regional, national and local Human Development Reports. Millennium Development Goals (MDGs) adopted in September 2000 to be achieved by 2015 for: (i) Eradication of poverty, hunger and malnutrition, (ii) Giving quality primary education to children, (iii) Promoting gender equality and working for empowerment of women, (iv) Reducing child malnutrition, (v) Improving maternal health, (vi) Curing AIDS, malaria and other diseases, (vii) Ensuring sustainable 
development, and (viii) Developing global partnership. All countries of UN agreed to help achieving sustainable development and economic growth by following MDGs.

Complete sustainable development cannot be achieved within 15 years it takes a lot of time to achieve hence in January 2016 SDGs have been prescribed followed by MDGs to be achieved by 2030. SDGs include: (i) Eradication of poverty, (ii) Ending hunger and malnutrition, (iii) Ensuring health facilities and promoting wellbeing of the people, (iv) Providing quality education to all and promoting lifelong learning opportunities for all, (v) Promoting gender equality and working for empowerment of women, (vi) Ensuring pure drinking water and sanitation, (vii) Ensuring reliable, affordable modern electricity for all, (viii) Ensuring economic growth by creating job opportunities for unemployed people, (ix) Promoting industry, innovation and infrastructure, (x) Reducing income inequality, (xi) Creating safe, resilience and sustainable cities and communities, (xii) Ensuring sustainable consumption and production of goods, (xiii) Ensuring environmental sustainability, (xiv) Protecting life below water, (xv) Protecting life above land, (xvi) Promoting peace, justice and strong institutions, and (xvii) Developing global partnership for sustainable development.

\section{Method}

An analysis of SDGs under Islamic law is topic of this research which is rooted in qualitative method to recognize importance of locating research within social, cultural, religious, international and historical context under the light of relevant Islamic legal text and International Statutes. This study is conducted using qualitative method of research to analyze SDGs under verses of Holy Qur'an and Traditions of Prophet Muhammad to study and elaborate objective ideas for betterment of the society. Therefore, this study is aimed to analyze, review and compare SDGs with Islamic law under the light of Holy Qur'an and Sunnah of Prophet Muhammad 轿. 
TIFBR | Tazkia Islamic Finance and Business Review

Volume 12(1), 2018

\section{Result and Disscussion}

\section{Sustainable Development Goals under Islamic Law}

Islamic law is revelation of Almighty Allah revealed to the last Prophet Muhammad 糍 for betterment of human beings in both worlds. Holy Qur'an and Sunnah of Prophet Muhammad are 2 main basic sources of Islamic law. Islam is the only religion of Almighty Allah as Almighty Allah states, "Truly, the religion with Almighty Allah is Islam" (Ali Imran [3]: 19). And He also states, "Whoever seeks religion other than Islam, it will never be accepted from him" (Ali Imran [3]: 85).

Verses of Holy Qur'an dealing with conduct of human beings are classified into faith, character, worship, transactions, offences and their punishments. Prophet Muhammad explained verses of Holy Qur'an through his sayings, practices and by aggreging on practices of his companions (Kamali, 2003). SDGs are required to be achieved by 2030 for continuous sustainability and economic growth in the world. Islamic law emphasizes on economic growth by providing proper economic system for achieving continuous sustainability in the world. Objectives of Islamic law includes (i) Preservation of religion, (ii) Preservation of life, (iii) Preservation of intellect, (iv) Preservation of progeny, and (v) Preservation of wealth (Kamali, 2008; Chapra et al., 2008).

After studying SDGs and reviewing verses of Holy Qur'an and traditions of Prophet Muhammad 龇, it is conferred that SDGs come under objectives of Islamic law and has been explained comprehensively way back 1400 year ago by Almighty Allah in Holy Qur'an and by Prophet Muhammad 能 in his traditions.

SDGs require member states to (i) Create peace, provide justice and establish strong institutions by reducing violence, resolving conflicts, strengthening rule of law and promoting human rights, (ii) Reduce inequality by economic growth through inclusion of all without discrimination as to sex, 
race, place of birth, (iii) End all forms of discrimination and exploitation against women by eradicating sexual violence, (vi) Achieve global health by curing AIDS, malaria, tuberculosis and provide public access to safe and affordable medicines, (v) Provide quality education to all by eliminating gender inequality and wealth disparity, (vi) Provide public access to affordable pure drinking water and sanitation, (vii) Provide public access to affordable electricity, (viii) Create efficient disaster management cell for tsunami, earthquake, tropical cyclone and flooding, (ix) Invest in infrastructure, innovation and scientific research by providing equal access of information and knowledge to public, (x) Protect life under water by reducing pollution, (xi) Protect rivers, mountains, wetland, dryland and forests, (xii) Create sustainable cities by investing in safe and affordable houses, public transport, green public places and settlement of slums, (xiii) Create effective system of production, consumption, disposing off and recycling goods, (xiv) Create productive job opportunities for all without discrimination as to sex, race, ethnicity, (xv) Eradicate poverty by providing pure and affordable drinking water, food and sanitation to public, (xvi) End hunger and malnutrition by providing nutritious food to children, supporting farmers having equal access to land, technology and market to increase agriculture productivity for economic growth, and (xvii) To promote international trade by helping developing countries to increase exports, achieve sustainable development and liberalize trade from government intervention (Blanc, 2015).

SDG No.16 dealing with promotion of peace, justice and strong institutions which all come under protection of religion in Islamic law. Islam is derived from root word salam which means peace hence a person entering Islam is entering peace and submitting his will to Almighty Allah and comes under his protection. Islam speaks about justice and encourages it even with enemies as Almighty Allah says,

"O you who believe! Stand out firmly for Allah and be just witnesses and let not enmity and hatred of others make you avoid justice. Be 
just: that is nearer to piety and fear Allah. Verily, Allah is Well Acquainted with what you do" (Al-Maidah [5]: 8).

"O you who believe! Stand out firmly for justice as witnesses to Allah even though it be against yourselves or your parents or your kin, be rich or poor, Allah is Better Protector to both (than you), so do not follow lusts (of your hearts), lest you may avoid justice and if you distort your witness or refuse to give it, verily, Allah is ever well acquainted with what you do" (An-Nisa [4]: 135).

Islam even goes ahead and speaks about justice inside family and asks parents to do justice among their children as narrated by Amir,

He heard An-Nu'man bin Bashir on the pulpit saying: "My father gave me a gift but 'Amra bint Rawaha (my mother) said that she would not agree to it unless he made Allah's Messenger as a witness to it. So, my father went to Allah's Messenger and said: I have given a gift to my son from 'Amra bint Rawaha but she ordered me to make you witness to it, O Allah's Messenger Allah's Messenger asked: Have you given (the like of it) to everyone of your sons? He replied in the negative. Allah's Messenger said, be afraid of Allah and be just to your children. My father then returned and took back his gift." (Sahih Al-Bukhari 2587).

Injustice includes killing innocent human beings is considered killing whole humanity in Islamic law and saving life is considered saving whole humanity. Almighty Allah says,

"If anyone killed a person not in retaliation of murder or (and) to spread mischief in the land, it would be as if he killed all mankind and if anyone saved a life, it would be as if he has saved life of all mankind. And indeed, there came to them Our Messengers with clear proofs, evidences and signs even then after that many of them continued to exceed limits (e.g. by doing oppression unjustly and exceeding beyond limits set by Allah by committing major sins) in the land" (An-Nisa [4]: 32). 
Islam does not promote violence and have made a strong punishment for people who participate in violence and disturb peace of the society. Almighty Allah says,

"Recompense of those who wage war against Allah and His Messenger and do mischief in land that they shall be killed or crucified, or their hands and their feet be cut off on opposite sides or be exiled from the land. That is their disgrace in this world and a great torment in the Hereafter. As for those who repent before you (legal authorities) have control over them (by proving them guilts). They should know that God is All-forgiving, All-merciful" (AlMaidah [5]: 33-34).

SDG No.16 imbedded resolution of disputes as Islamic law requires third party to become facilitator of peace among disputing parties as Almighty Allah says,

"And if two parties or groups among believers fall to fighting then make peace between them both but if one of them rebels against the other then fight you (all) against the one that/which rebels till it complies with the command of Allah then if it complies then make reconciliation between them justly and be equitable. Verily! Allah loves those who are equitable" (Al-Hujurat [49]: 9).

Islam also promote reconciliation among husband and wife as Almighty Allah says,

"If you fear breach between them twain (man and his wife), appoint (two) arbitrators, one from his family and the other from wife's, if they both wish for peace, Allah will cause their reconciliation. Indeed, Allah is ever all knower, well acquainted with all things" (An-Nisa [4]: 35).

"And if a woman fears cruelty or desertion on her husband's part, there is no sin on them both if they make terms of peace between themselves and making peace is better. And human inner-selves are swayed by greed but if you do good and keep away from evil, verily, Allah is ever well acquainted with what you do"(An-Nisa [4]: 128). 
Islam requires Islamic Government to establish institutions for public welfare as Almighty Allah says,

"If We give (moslem rulers) power/authority in land (they) enjoin
(establish through order) (i) performance of congregational prayers
(in mosques), (ii) payment of compulsory charity/zakah, (iii)
spreading good (all that Islam orders one to do), and (iv) forbid/repeal
harm (all that Islam has forbidden)" (Al-Hajj [22]: 41).

Islamic law emphasis on spreading good and forbidding harm, therefore a separate institution was established in the reign of second caliph Umar RZ known as Hisbah and its chief is known as muhtasib/ombudsman also called sahib-ul-sooq/amil-ul-sooq. Muhammad Bin Muslima RZ was the first chief muhtasib in the reign of Umar RZ. Hisbah is a department required to be created by Federal Government where there is a chief muhtasib at Federal level and there are other muhtasibs in different parts of the State for providing/giving justice to public at the spot (Islahi, 2006). Rules of muhtasib are derived from verses of Holy Qur'an where Almighty Allah says that good people always encourage people to do good things and preventing people from wrongdoings (Ali Imran [3]: 104; Ali Imran [3]: 114; Yunus [10]: 71). Prophet Muhammad said,

"If you see a wrong, stop it from your hand, if you are not capable from stopping it from hand, stop it from your tongue, if you still not capable to stop it from your tongue then hate it in your heart and it is the least degree of faith" (Sahih Muslim 186).

SDG No.10 deals with elimination of inequality among countries and SDG No.5 dealing with gender equality and empowerment of women which also come under protection of religion as these are religiously required rules under Islamic law that all people are equal before law and there is no discrimination between rich and poor, man and woman before law (Spierings, Smits and Verloo, 2009). Absolute equality does not exist anywhere in the world, the equality which is required everywhere is equality before law. All 
men and women are equally treated before law and whosoever (men and women) do good deed will be rewarded for that. Almighty Allah says,

"Believers men and women, are helpers/supporters/protectors of one another, they enjoin good (all that Islam orders one to do) and forbid (people) from bad (all that Islam has forbidden); they perform prayers and give compulsory charity/zakah and obey Allah and His Messenger Allah will have His Mercy on them. Surely Allah is Almighty, All-Wise. Allah has promised believers (men and women) gardens under which rivers flow to dwell therein forever and beautiful mansions in gardens of 'Adn (Eden Paradise) but the greatest bliss is the Good Pleasure of Allah. That is the supreme success"(At-Taubah [9]: 71-72).

It is pertinent to mention that Islamic law does not recognize and protect sexual rights of Lesbian, Gay, Bisexual and Transgender persons (LGBT). Islamic law has no space for unnatural lust therefore a strong punishment is prescribed in Holy Qur'an and Sunnah of Prophet Muhammad for Lesbian and Gays. The only protected genesis is the naturally born transgender persons whose rights are protected but unnatural Gays and Lesbians are required to be treated with strong hands and punished for their unnatural activities as per prescribed provisions of Holy Qur'an and Sunnah of Prophet Muhammad (Sunan Abu Dawud 4462).

Islam teaches human beings rights and duties derived from sources of Islamic law. Human beings are required to have knowledge and capacity to acquire right and execute duty. SDGs include reduction of inequality by economic inclusion of all without discrimination as to sex, race, and place of birth. Islamic law does not discriminate between male and female before law as per their wealth. Almighty Allah says,

"For men there is reward for what they have earned, (and likewise) for women there is reward for what they have earned and ask Allah of His bounty. Surely, Allah is ever all knower of everything" (An-Nisa [4]: 32). 
"O mankind! We have created you from male and female and made you into nations and tribes that you may know one another. Verily, the most honorable of you with Allah is that (believer) who is pious. Verily, Allah is All-Knowing, All-Aware" (Al-Hujurat [49]:13).

Prophet Muhammad stated in his last sermon during pilgrimage that Arabic person is not superior than non-Arabic person and non-Arabic person is not superior than Arabic person, similarly reddish person has no superiority over black person nor black has superiority over reddish except for piousness (Musnad Ahmad ibn Hanbal 24204).

Islamic law encourages elimination of discrimination and exploitation against women by eradication of sexual violence. There is a severe punishment for fornication and punishment for a person who blames women of adultery without producing 4 pious witnesses otherwise the accuser will be awarded punishment of 80 lashes and his witness will never be accepted in future except he repents and do good deeds (Mukhtar, 2016). Almighty Allah says,

"Woman and man guilty of illegal sexual intercourse flog each of them with hundred stripes. Let not pity withhold you in their case in a punishment prescribed by Allah if you believe in Allah and the Last Day. And let a party of believers witness their punishment. (This punishment is for unmarried person guilty of the above crime but if married person commits it, the punishment is to stone him to death according to Allah's law). Adulterer marries not but an adulteress or a pagan woman and adulteress none marries her except adulterer or pagan man [and that means that man who agrees to marry (have a sexual relation with) pagan (female polytheist or idolatress) or prostitute, then surely, he is either adulterer or pagan (polytheist or idolater) And woman who agrees to marry (have a sexual relation with) a pagan (polytheist or idolater) or adulterer then she is either prostitute or pagan (female polytheist or idolatress). Such a thing is forbidden to believers (of Islamic Monotheism)" (An-Nur [24]: 2-3).

"And those who accuse chaste women and do not produce four witnesses, flog them with eighty stripes and reject their testimony forever, they indeed are liars/rebellious/disobedient to Allah. Except 
those who repent thereafter and do righteous deeds, (for such) verily, Allah is off-forgiving, Most Merciful. And for those who accuse their wives but have no witnesses except themselves, let the testimony of one of them be four testimonies (i.e. testifies four times) by Allah that he is one of those who speaks the truth. And the fifth (testimony) (should be) invoking curse of Allah on him if he be of those who tells a lie (against her). But it shall avert the punishment (of stoning to death) from her if she bears witness four times by Allah that he (her husband) is telling a lie. And the fifth (testimony) should be that the wrath of Allah be upon her if he (her husband) speaks the truth. And had it not been for the grace of Allah and His mercy on you (He would have hastened the punishment upon you)! And that Allah is the One who accepts repentance, All-Wise" (An-Nur [24]: 4-10).

SDG No.3 dealing with ensuring healthy life by curing AIDS, malaria, tuberculosis and other deceases and provide safe and affordable medicines to all which comes under ambit of protection of life in objectives of Islamic law. Islamic law puts a strong emphasis on healthcare thus has laid down principles for safe, secured and healthy life. Prophet Muhammad said,

"A strong believer is better and dearer to Allah than a weak one and both are good. Adhere to that which is beneficial for you. Keep asking Allah for help and do not refrain from it. If you are afflicted in any way, do not say: If I had taken this or that step, it would have resulted into such and such but say only: Allah so determined and did as He willed. This word opens gates of evil thoughts" (Sahih Muslim 6954).

Narrated Usamah ibn Sharik, I came to Prophet and his companions were sitting as if they had birds on their heads. I saluted and sat down. Desert Arabs came from here and there. They asked: Messenger of Allah should we make use of medical treatment? He replied: Make use of medical treatment for Allah has not made a disease without appointing a remedy for it except for one disease, namely old age (Sunan Abu Dawud 3855).

SDG No. 4 dealing with equitable quality education and lifelong learning opportunities for all without discrimination which comes under protection of life, intellect and progeny under objectives of Islamic law (Kadi, 2006). Islamic law emphasis on learning as first revelation of Almighty Allah 
on Prophet Muhammad started with the word "read" (Al-'Alaq [96]: 1).

Almighty Allah appreciates knowledgeable person, He says,

"O you who believe! When you are told to make room in assemblies, (spread out and) make room. Allah will give you (ample) room (from His mercy). And when you are told to rise [for prayers, Jihad (holy fighting in Allah's cause) or for any other good deed], rise. Allah will exalt in degree those of you who believe and those who have been granted knowledge. And Allah is Well-Acquainted with what you do" (Al-Mujadalah [58]: 11).

Prophet Muhammad used to make prayers that “...my Lord! Increase me in knowledge" (Taha [20]: 114). Islamic law emphasis on education as Prophet Muhammad said,

"If anyone travels on a road in search of knowledge, Allah will cause him to travel on one of the roads to Paradise. Angels will lower their wings in their great pleasure with one who seeks knowledge, inhabitants of the heavens and the Earth and fish in deep waters will ask forgiveness for the learned man. The superiority of learned man over devout is like that of the moon on the night when it is full over rest of stars. The learned are heirs of Prophets and Prophets leave neither dinar nor dirham (currencies) leaving only knowledge and he who takes it takes an abundant portion" (Sunan Abu Dawud 3641).

It is pertinent to mention that spreading knowledge and forbidding illiteracy is the primary duty of every state and for that purpose the State is required to collect zakah from the wealth of rich and use money for spreading knowledge in the society. Giving zakah is one of the pillars of Islamic law and he who does not believe in paying zakat cannot be considered a moslem as Almighty Allah says,

"But if they repent, perform prayers and give zakah then they are your brethren in religion. (In this way) We explain the ayat (proofs, evidences, verses, lessons, signs, revelations, etc.) in detail for a people who know" (At-Taubah [9]: 11). 
Apart from compulsory charity which is obligatory upon a rich person having more assets general charity sadaqa is also recommended as Almighty Allah says, "And they ask you what they ought to spend. Say that which is beyond your needs, thus Almighty Allah makes clear to you His laws in order that you may give thought" (Al-Baqarah [2]: 219).

Another way to provide equal education facilities to all is to use the method of waqf /trust for benefits of people. Almighty Allah says, "By no means shall you attain righteousness unless you spend of that which you love and whatever of good you spend, Allah knows it well" (Ali Imran [3]: 92).

Prophet Muhammad said "When a man dies his deeds come to an end, except for three (i) continuous charity, (ii) knowledge by which people derive benefit, and (iii) pious son who prays for him" (Sahih Muslim 7/55). He also said that "He who has (surplus) land should donate it (to others) or lend it" (Sahih Muslim 1536u). When Umar RZ got a piece of land in Khaibar, he came to the Prophet saying: I have got a piece of land better than which I have never got, so what do you advise me regarding it? Prophet said: If you wish you can keep it as an endowment to be used for charitable purposes. So, Umar RZ gave the land in charity as an endowment on a condition that the land would neither be sold nor given as a present nor bequeathed (and its yield) would be used for the poor, the kinsmen, the emancipation of slaves, Jihad, and for guests and travelers; and its administrator could eat in a reasonable just manner and he also could feed his friends without intending to be wealthy by its means (Sahih Al-Bukhari 2772).

Islamic law has established principles for proper Islamic Economic System which is based upon no harm to others and no gain without possibility of loss principles (Manșūrī, 2001). Usury is prohibited as it is beneficial for one party and harmful for weak party; it is either increase from one side in exchange of goods or increase while paying back the debt. Almighty Allah has prohibited usury and permitted sale including lawful trade and investment activities. Transactions in which subject matter is 
ambiguous and uncertain is also not allowed as well as gambling and game of chance to protect weak parties and to eradicate bad practices from the society (Razali, 2010).

One of the activities to eradicate poverty and help needy persons of society is compulsory charity/zakah which is obligatory upon rich person $2.5 \%$ on saved assets value of which is more than 7.5 tola gold or 52.5 tola silver after completion of one year. Generally, word sadaqa is used for all types of charities in Islamic law, its plural is sadaqat as zakah is the Arabic word which is specifically used for compulsory charity as it literally means purification and defined as purification of specified wealth after completion of one year (Adnan and Bakar, 2009). Moslems are required to pay charity/zakah to people come under one of these prescribed categories (i) poor, (ii) person does not have enough money to fulfil his needs, (iii) employed to collect (funds), (iv) for attracting hearts of those who have been inclined (towards Islam), (v) to free captives, (vi) those in debt, (vii) for Allah's cause, and (viii) for wayfarer (traveler), a duty imposed by Almighty Allah (At-Taubah [9]: 60).

SDG No.6 dealing with providing affordable pure drinking water and sanitation to public which is necessary for protection of life. Purity is half religion as Prophet Muhammad 䚙 said,

"Cleanliness is half of faith and Al-Hamdu Liliah (Praise be to Allah) fills the scale and Subhan Allah (Glory be to Allah) and Al-Hamdu Lillah (Praise be to Allah) fill up-what is between the heavens and the earth and prayer is light and charity is proof (of one's faith) and endurance is brightness and Holy Qur'an is proof on your behalf or against you. All men go out early in the morning and sell themselves thereby setting themselves free or destroying themselves" (Sahih Muslim 223).

Providing pure affordable drinking water is a matter needs to be resolved by Governments and they are required to tackle this issue with good strategy as rich people can afford mineral water and poor people cannot 
afford hence it is duty of the Government to provide them pure drinking water. $70 \%$ of human body requires water hence pure water is a life and there is no life without water therefore member states are required to take strong steps towards cleaning water process and make it available to public at their doorsteps (Al Denio, 2011). Another thing attached with pure drinking water is food which is dealt under SDGs No.1 and 2 for prevention of poverty, hunger and malnutrition and there is also a requirement for establishment of proper system of production, consumption, disposing off and recycling goods under SDG No. 12.

SDG No. 7 dealing with affordable modern energy to be provided to public which has become necessity nowadays and life cannot be lived without electric appliances. It is pertinent to mention that electricity is necessity nowadays and the Government cannot claim taxes on necessities under Islamic law. The Government is required to provide all necessary things to public in affordable prices without putting taxes on necessities as taxes can only be placed on luxuries and not on necessities as Almighty Allah says, "And they ask you what they ought to spend. Say: 'That which is beyond your needs.' Thus, Allah makes clear to you His Laws in order that you may give thought" (AlBaqarah [2]: 219).

SDG No.15 dealing with protection of life over land by protecting rivers, hills and forests and for that purpose disaster management cells are required to be established. SDG No 14 dealing with protection of life under water and SDG No.13 dealing with protection of environment. Islamic law requires the Government to foresee upcoming challenges and prepare for future disasters and problems by creating efficient and effective disaster management cells for different kinds of disasters to save humanity. Protecting forests and taking care of animals are also encouraged in Islamic law and it is considered charity as Prophet Muhammad said,

"While a man was walking he felt thirsty and went down a well and drank water from it. On coming out of it, he saw a dog panting and 
eating mud because of excessive thirst. The man said, this (dog) is suffering from the same problem as that of mine. So, he (went down the well) filled his shoe with water, caught hold of it with his teeth and climbed up and watered the dog. Allah thanked him for his (good) deed and forgave him. The people asked, "O Allah's Messenger there a reward for us in serving animals?" He replied, "Yes, there is a reward for serving any animate" (Sahih Al-Bukhari 2363).

"When a man dies, his acts come to an end but three (i) continues charity, (ii) knowledge (by which people) benefit, and (iii) pious son prays for deceased" (Sahih Muslim 1631).

SDG No.9 dealing with infrastructure, innovations and industrialization. Islamic law encourages positive thinking for innovation and scientific research as Almighty Allah says, "Verily! In the creation of heavens and earth and in alternation of night and day, there are indeed signs for men of understanding" (Ali Imran [3]: 190).

SDG No. 8 dealing with creation of jobs, industrialization and economic growth. Economic growth follows human growth if you spend on human beings, on their education, on pure drinking water and affordable food and electricity and other necessities as well as medical facilities, human beings will automatically start thinking positively which leads towards innovation and economic growth and will help building new modern cities with all required facilities which is requirement under SDG No.11 (Blanc, 2015).

SDG No.17 deals with development of Global Partnership. Islamic law asks human beings to live peacefully and make contacts with each other and help each other in good things and eliminate harm from the society and make debates with wisdom without fighting and resolve disputes through peaceful means. Almighty Allah says,

"And let not hatred of some people stopping you from Al-Masjid-AlHarâm (at Makkah) lead you to transgression (and hostility on your part). Help you one another in virtue/righteousness/piety) but do not 
TIFBR | Tazkia Islamic Finance and Business Review

Volume 12(1), 2018

help one another in sin and transgression. And fear Allah. Verily,

Allah is Severe in punishment" (Al-Maidah [5]: 2).

\section{Conclusion}

MDGs entered into force in 2000 and SDGs in 2016 under UNDP to be achieved for sustainable development in the world. Islamic law has prescribed principles 1400 years ago in Holy Qur'an and Sunnah of Prophet Muhammad dealing with (i) Protection of life, intellect, progeny and wealth, (ii) Promotion of justice, peace, prosperity, education, healthcare, women's rights, (iii) Elimination of discrimination, poverty, hunger, malnutrition, and injustice. Islamic law is a complete code of life providing guidelines in every aspect of life comprehensively defined in Holy Qur'an

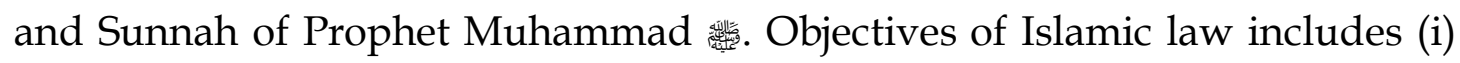
Protection of religion, (ii) Protection of life, (iii) Protection of intellect, (iv) Protection of progeny, and (v) Protection of wealth. When we look at SDGs and compare them with objectives of Islamic law, one can understand that what SDGs demand, comprehensively described and demanded 1400 years ago in Holy Qur'an and Sunnah of Prophet Muhammad and practically enforced by Muhammad and his Rashidun Caliphate 40 years after him. It is therefore recommended that SDGs should be followed by all countries in a true sense for betterment of humanity and the world and as a moslem we believe for betterment of hereafter as well.

\section{References}

Al- Qur'an. English Translation by Yusuf Ali.

Abu Dawud. Sunan Abu Dawud. Retrieved from https://sunnah.com/abudawud

Adnan, M.A. and Bakar, N.B.A. (2009). Accounting Treatment for Corporate Zakat: A Critical Review. International Journal of Islamic and Middle Eastern Finance and Management, Vol. 2 (1): 32-45.

Aḥmad bin Ḥanbal. Musnad Ahmad ibn Hanbal.

Al-Bukhari. Sahih Al-Bukhari. Retrieved from http://sunnah.com/bukhari 
Al Denio. (2011). Pure Drinking Water. Chemical \& Engineering News, Vol. 89 (33): 4-4.

At-Tirmidhī. Jami At-Tirmidhi. Retrieved from https://sunnah.com/tirmidhi

Chapra, M.U. Khan, S. and Al Shaikh-Ali, A. (2008). Islamic Vision of Development in the Light of Maqasid Al-Shariah. International Isntitute of Islamic Thought (IIIT). London, Washington.

Islahi, A.A. (2006). Works on Market Supervision and Shar'iyah Governance (Al-Hisbah wa Al-Siyasah Al-Shar'iyah) by The Sixteenth Century Scholars. Islamic Economics Research Centre. Jeddah, Saudi Arabia.

Kadi, W. (2006). Education in Islam-Myths and Truths. Comparative Education Review, Vol. 50 (3): 311-324.

Kamali, M.H. (2003). Principles of Islamic Jurisprudence. Islamic Texts Society. Cambridge, United Stated of America.

Kamali, M.H. (2008). Maqasid al-Shariah Made Simple. International Institute of Islamic Thought (IIIT). London, Washigton.

Le Blanc, D. (2015). Towards Integration at Last? Sustainable Development Goals as a Network of Targets. Sustainable Development, Vol. 23 (3): 176187.

Manșūrī, M.T. (2001). Islamic Law of Contracts and Business Transactions. Shari'ah Academy. International Islamic University Islamabad, Pakistan.

Mukhtar, S. (2016). In Defense of The Codification of The Islamic law of Hudud into The Law of Pakistan. International Review of Law, (2) 11.

Muslim. Sahih Muslim. Retrieved from https://sunnah.com/muslim

Razali, S.S. (2010). Islamic Law of Contract. Cengage Learning Asia Singapore.

Spierings, N. Smits, J. and Verloo, M. (2009). On the Compatibility of Islam and Gender Equality. Social Indicators Research, Vol. 90 (3): 503-522. 